\title{
Avant-Retard, para Flauta em Do e Flauta em Sol
}

\author{
Sílvia de Lucca \\ compositora \\ silviadelucca@hotmail.com
}

\section{Comentário sobre a obra}

A peça Avant-Retard (1991) de minha autoria, um duo para flauta em Do e flauta em Sol, de aproximadamente 5 minutos, teve sua linguagem inspirada pelo 'serialismo' do compositor francês Olivier Messiaen (1908-1992) usado em sua peça Modo de Valores e Intensidades que eu acabara de analisar durante o curso de Especialização em Composição que frequentava no Conservatório de Música Genebra (Suíça). Ela continha atmosfera de alguma forma similar a outra peça dele mesmo que eu havia conhecido e analisado no Brasil em 1985, a Abismo dos Pássaros: trama sonora em quadros (ou imagens, caso pensemos no impressionismo) que se encadeiam com fluidez, organicamente. Ambas as peças remetem a uma sensação de atemporalidade, de já terem sido iniciadas não se sabe quando e de virem a continuar para além, cabendo ao intérprete do piano e do clarinete, respectivamente, executar somente uma fração do que elas efetivamente seriam e pairam no ar. Certo é que essa impressão não é fruto unicamente do serialismo empregado que se contrapôs propositalmente ao ‘jeito’ de existir e acontecer do exvigente 'tonalismo', novo marco esse estabelecido pelo austríaco Arnold Schönberg, mas resultado de um ambiente cultural que desenvolveu a escuta de quem toma a decisão estética no momento da criação, qual seja, o compositor.

Ou seja, deixei-me seduzir pelo que considero uma atmosfera francesa nesta peça, acima de tudo etérea e sensorial, de leveza e luminosidade, apesar do esquema formal determinando com rigor diferentes elementos estruturais. As três razões para isso eram claras: devido à nacionalidade de Messiaen; por eu residir em Genebra, historicamente e geograficamente relacionada à França; pela proximidade indireta a outro compositor que eu melhor conhecia e passava a admirar, o franco-suíço Arthur Honegger (1892-1955). Para tanto, optei pelo 'modalismo' livre, ou melhor, 'bimodalismo’ livre pelo uso simultâneo das escalas modais Lídio e Lócrio, diametralmente distintas no que se refere a claro-escuro, ou seja, com a consciente intenção de trabalhar com cores, o que sabidamente a cultura francesa soube bem explorar. Para essa finalidade específica fiz a escolha de duas flautas, cuja sonoridade serviria muito bem, haja 
visto o que magistralmente fez o também francês Debussy em seu Prelúdio ao entardecer de um fauno.

A propósito dessa opção francesa pontual, durante uma entrevista realizada pelo jornal Tribuna da Imprensa Livre - dentro da série Compositoras e Compositores do Brasil -, ao ser perguntada pelo seu Diretor Executivo, Luiz Carlos Prestes Filho, se o fato de eu ter bebido na fonte da cultura brasileira foi importante para o surgimento de minha linguagem como compositora e ainda, se minha identidade musical brasileira era reconhecida pelos professores quando estudei no exterior, pude responder da forma que segue:

\begin{abstract}
Crescer mergulhados na diversidade cultural brasileira, deixando-nos envolver, passa a ser uma notável marca internacional de maleabilidade em qualquer área, creio eu. Nossas fronteiras pessoais se alargam sobremaneira e, aparentemente, com uma satisfação peculiar. Talvez isso justifique porque colegas compositores das últimas gerações, ao conhecer novas propostas e técnicas, trafegaram de uma estética a outra de modo mais ou menos orgânico com aparente facilidade, nada devendo sobre o compromisso e domínio em cada uma. A fidelidade a uma determinada linguagem, quando existia, era pontual: "que seja eterno o quanto dure!”, já disse o poeta (LUCCA, apud PRESTES FILHO, s.d.).
\end{abstract}

Paralelamente à atmosfera predominante que desejava na composição que iniciaria, e tendo recém confirmado que Messiaen mostrou a possibilidade de manter sua autoria criativa, apesar do largo controle pré-concebido que o fazer serial requer, ao conduzir vários dos elementos musicais com claras ordenações e limites, a opção para eu compor utilizando essa técnica deu-se pela curiosidade em passar uma vez mais pela experiência, dessa vez de modo mais estrito segundo a subclassificação 'serialismo integral'. A respeito escreve Henderson Rodrigues dos Santos (2015):

Na década de 50, o serialismo passa a ser o método mais utilizado para compor. Muitos compositores buscaram associar o método a seus gostos pessoais. Roberto Gerhard aplicou um colorido tipicamente espanhol, Krenek trocou o estilo do Jazz pelo serialismo na ópera Karl V, Frank Martins enriqueceu a harmonia francesa com técnicas seriais, entre outros.

Mas foi com Messiaen que os princípios seriais foram estendidos aos demais parâmetros da música como a dinâmica e o ritmo. Em sua peça Mode de Valeurs et d’Intensités, Messiaen propõe a utilização de séries para a intensidade, a duração e ataque, e, embora sua peça não seja dodecafônica, e sim modal, ela abriu caminho para o que se tornou conhecido como serialismo integral.

Para essa segunda tomada de decisão, a linguagem escolhida, eu sabia contar com o apoio de meu então orientador. Diferentemente de meus ex-professores no Brasil, os dois suíços Lehmann em Zurique e Balissat em Genebra - tinham especial vivência e apreço pela chamada Segunda Escola de Viena, o que certamente foi um importante referencial para mim, mesmo que 
indiretamente, pois embora não me identificasse com essa linguagem em si, já reconhecia a importância de melhor conhecê-la e questionava sobre como utilizá-la a meu critério. Inclusive e curiosamente, a mim foi marcante, porém compreensível, que meu orientador Hans Ulrich Lehmann tenha admitido com relativa modéstia no decorrer do curso que pouco poderia assessorar-me a respeito de meu estilo estético, então já reconhecido por ele como pessoal, ele que estava na importante função de Diretor do Conservatório de Zurique durante muitos anos, tendo sido aluno justamente de Messiaen e Stockhausen, ícones dessa nova linguagem.

A despeito de minha estética composicional, vale acrescentar que naquela época, bem como na atualidade, não é prioritariamente o estilo, linguagem ou gênero que conquistam a minha atenção, interesse e gosto. Considero e trato essas delimitações como simples 'meios’ de se atingir resultados, finalidades e objetivos específicos, sejam pessoais ou para além disso. Desse modo, sinto-me potencialmente interessada e inserida, mesmo que indiretamente, em toda ação, manifestação, proposta e evento que de fato conceba a diversidade dentro do nicho ‘contemporâneo’ em que estamos genericamente classificados.

Lembrando que os períodos de tempo dentro da chamada ‘música de concerto’ são largos, incondicionalmente nos séculos XX e XXI encontra-se representada uma imensurável variedade estética e, dentro de tamanho espectro, sinto-me sempre arrebatada pelas obras que expressam a música de um ser pleno, organicamente, honestamente e intuitivamente, tal qual são as impressões digitais que cada um prega em tudo sem sequer perceber. É a 'autoria' enfim que me encanta nestes e em geral, o poder, a capacidade, a independência, a coragem de expressar o mundo e a vida como verdadeiramente interpretam, acima de tudo para si mesmos. E, junto com isso a valorização do métier, o qual possibilita que nós compositores tenhamos condições de bem 'traduzir' e ‘decodificar' nossas idéias sonoramente e graficamente. Foi o caso de Schönberg e Messiaen, logo modelos à minha própria trajetória. Tomo esses dois europeus para exemplificar o meu parecer enquanto brasileira porque a maioria das novas correntes da chamada música erudita pós anos 50 (findado o período das grandes guerras) também começaram e se estabeleceram naquele Continente, logo, a tendência natural é que aqueles conceitos e grafias ainda sirvam suficientemente para inclusive nos representar, o que acredito não ser uma exceção no mundo ocidental. 
Relativo ao meu próprio processo de composição, tudo torna-se compatível com os conceitos que expus. A partir disso bem definido e delineado, e ciente dos instrumentos que executarão a obra e do tempo que ela deve durar, parto para os respectivos cálculos em busca minuciosa dos elementos musicais mais bem apropriados e de ‘como’ deverei interconectar todas as variáveis para enfim produzir o efeito expressivo almejado. Dito assim, pode parecer um processo demasiadamente racional, mas cada etapa dessa envolve muita criatividade, além de me tomar por completo, dentro disso também a ‘montagem’ da(s) série(s) que servirão de módulos para a construção da obra, tal qual tijolos em uma construção física.

No caso específico de Avant-Retard, ter decidido por dois instrumentos sonoramente similares em extensão e timbre, com a principal diferença entre eles sendo a 'altura' (agudograve) - flauta em Do e flauta em Sol - tinha também o seu propósito, o de eliminar hierarquias, algo também característico do ‘serialismo’. Procurei deixar isso evidenciado na escrita, tanto na linha de cada uma, como na rede entre ambas, pois a tendência habitual seria a de tratar a flauta mais aguda como principal e a mais grave como acompanhante. Por conseguinte, dependendo do momento, ora acontece de não haver qualquer material em uma delas que requeira atenção sonora especial, como 'célula', 'motivo’ ou ‘frase’ (essa ausência também caracteriza a linguagem serial), logo o protagonismo fica automaticamente eliminado, ora esses materiais existem de algum modo, mas intercalados entre elas, de jeito que também assim não haja uma hierarquia definida.

Outro modo de não propiciar graduação entre as flautas foi a maneira de tratar a 'dinâmica', indo igualmente do ‘fraco fraquíssimo’ ao ‘forte fortíssimo’. Nas seções A e C há alternância constante nas duas em momentos independentes e na sessão B ambas têm a mesma 'dinâmica' em paralelismo. Portanto, nos dois casos, não se percebe importância taxativa de uma ou outra pelo recurso da 'intensidade'.

Ainda sobre esse elemento musical, vale revelar a intensão de uma relativa originalidade: normalmente os momentos mais importantes na música são realçados pela 'intensidade’ forte. Optei em fazer isso resumido em nove compassos pelas duas flautas no momento ápice de importância da peça, indo do fraco fraquíssimo ao forte fortíssimo e retornando ao fraquíssimo, ou seja, como um relativo efeito espelho quanto a aumentar e diminuir uma variável.

Para abordar enfim a 'série’ que criei, condição sine qua non para a linguagem pretendida, eu a idealizei referente aos ‘compassos’ da música: ‘binário’ (simples e composto), ‘ternário’ e 
‘quinário', e com duas unidades de base, as figuras ‘colcheia’ e ‘semínima’ (vide o esquema em anexo). A sequência deles na 'série’ está disposta também de forma espelhada, mas com relativa assimetria por causa da valorização do único ‘compasso quinário’ (5/8) dentro dela, colocado estrategicamente na posição indicada pelo que é conhecido como 'proporção áurea'. Escreve Leonardo Celuque (2004, p. 11):

[...] A Proporção Áurea é uma razão constante derivada de uma relação geométrica que, da mesma forma que o $\pi$ e outras constantes deste tipo, é irracional em termos numéricos [...]. Estes são números irracionais porque só podem ser aproximados e nunca podem ser expressos totalmente numa fração. A Série de Fibonacci está ligada a esta idéia única, a de uma Proporção Áurea, que tocava fortemente os Gregos antigos e foi usada repetidamente nas artes e na arquitetura [...].

Mais uma vez espelhada está a quantidade em que cada um dos compassos aparece, os quais na seção A diminuem gradativamente das pontas para o centro, porém um centro relativo, deslocado para a razão áurea, e depois na seção C a graduação quantitativa volta a crescer do centro rumo às margens. Esse movimento de ida e volta, contínuo e gradativo, acontece tendo uma importante pausa intermediária: na seção B, também localizada em momento ditado pela proporção áurea (uma vez considerada a duração total da obra), reina sozinho aquela 'fórmula de compasso’ citada acima, a 5/8. Vale dizer que, desse modo, aí sim, está evidenciada uma atípica hierarquia: um atípico compasso dominando a peça quantitativamente e em posição privilegiada.

Ainda a respeito da proporção ou razão áurea que foi um importante elemento estruturante na peça Avant-Retard, ela também balizou a organização do que podemos chamar de 'frases', no caso, por número de compassos, que também cresceram até o que seria um ponto culminante, respeitando aquela ‘proporção de ouro', para depois virem a decrescer gradativamente. Ainda Celuque (Ibid.):

A aplicação da Proporção Áurea à música tem sido muito freqüente. Bach e Beethoven, teriam-na utilizado. Debussy e Béla Bartók também. Em Debussy (1862-1918), a Proporção Áurea ocorre freqüentemente para controlar a forma e "vitalidade” da sua música. O clímax normalmente está inscrito numa peça na proporção de 0,618 do total [exemplo: numa peça de 100 compassos, o clímax ocorre no compasso $\sim 62(61,8)$.

Para finalizar, creio ser de interesse documentar a troca do título da peça em junho de 2009, do português Progressões Interrompidas para o francês Avant-Retard, pois o primeiro buscava ser autoexplicativo quando aos avanços graduais conforme explicado, bem como a existência dos 
momentos de 'pausa' de ambas as linhas durante a condução temporal, no caso, por meio de notas longas, efeitos percussivos e timbrísticos. O segundo título melhor simboliza, e com sutileza, a descrição das circunstâncias e propósitos gerais que envolveram a composição da peça, inclusive, indiretamente, o desenvolvimento de sua trama, ou seja, das citadas 'idas e vindas'.

\section{Referências}

CELUQUE, Leonardo. A Série de Fibonacci: um estudo das relações entre as ciências da complexidade e as artes. Dissertação (Mestrado em Ensino, Filosofia e História das Ciências). Salvador: UFBA /UEFS, 2004.

PRESTES FILHO, Luis Carlos. Silvia de Lucca: desejo e posso experimentar como compositora brasileira a diversidade que aqui está, mas sabendo não poder ou dever abarcar tudo. Por isso, deixo-me solta em minha própria linguagem. Em: Tribuna da imprensa livre: jornalismo em defesa do Brasil. Disponível em: https://tribunadaimprensalivre.com/silvia-de-lucca-desejo-e-posso-experimentarcomo-compositora-brasileira-a-diversidade-que-aqui-esta-mas-sabendo-nao-poder-ou-dever-abarcartudo-por-isso-deixo-me-solta-em-minha-propria-linguagem/.

RODRIGUES DOS SANTOS, Henderson. Um olhar na composição musical: a música serial do século XX. Em: Formação musical: blog com material acadêmico para quem quer aprender música. 8/3/2015. Disponível em: https://hendersonpessoal.wordpress.com/2015/03/08/serialismo-parte-ii/ 


\title{
Anexos
}

(371)

\author{
Partitura \\ Análises (manuscritos)
}




\section{AVANT-RETARD Duo para Flauta em Do e Flauta em Sol}

Silvia de Lucca

Zurique - 1991 
RM - 374 


\section{"AVANT-RETARD” *}

Duo para Flauta em Do e Flauta em Sol

"Avant-Retard" foi composta em 1991 por iniciativa pessoal, com dois objetivos principais: explorar a flauta como instrumento solista/camerista, em algumas de suas várias possibilidades, e atender a um plano formal ternário que havia recentemente idealizado, baseado em uma passacaglia e na proporção áurea, de acordo com cinco diferentes fórmulas de compasso e suas respectivas quantidades de compasso.

O título refere-se a determinadas progressões que são repetidamente interrompidas, feito que ocorre no discurso musical até atingir seu ponto culminante que, de modo pouco usual, caracteriza-se como o mais estável e calmo de toda a obra.

A título de informação, entre as duas flautas, embora de diferentes alturas, não existe hierarquia de valor, tendo ambas constantemente suas funções semelhantes ou simplesmente alteradas entre si.

\section{Silvia de Lucca}

17 de julho de 1991

* Alteração do nome original "Progressões Interrompidas", em junho de 2009 
RevistaMúsica, v 21 n. 2 - Dossiê O legado musical de Arnold Schoenberg e seus reflexos na América Latina: 1951-2021 Universidade de São Paulo, julho de 2021 ISSN 2238-7625 


\section{EXPLICAÇÃO DOS SINAIS}

(1) Tocar estas duas notas (re-sol) sem soprar, procurando obter um efeito percussivo.

(2) Tocar e, simultaneamente, cantar em uníssono com a flauta.

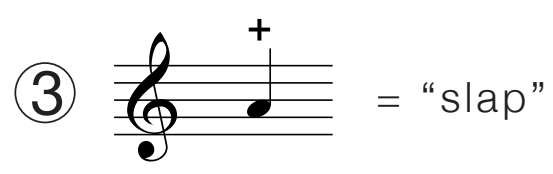

(4) Idem (1), porém com efeito "slap" simultaneamente.

(5) Percussão alternada entre os dedos polegar e mínimo da mão direita sobre as chaves seguintes: $\mathbb{O} \bigcirc \notin 0$

Fa\#

(6) Para a flauta em Do: em cada $\underline{5} \underline{0}$ tempo do compasso, subir a altura do som girando a flauta. É necessário haver uma progressão entre esses micro-intervalos, até alcançar o meio tom no fff. A flauta em Sol pratica o mesmo efeito, porém abaixando a altura do som.

\section{EXPLICATION DES SIGNES}

(1) Jouer ces deux notes (ré-sol) sans souffler, en cherchant l'effet de percussion.

(2) Jouer et, simultanément, chanter à l'unisson de la flûte.

(3)

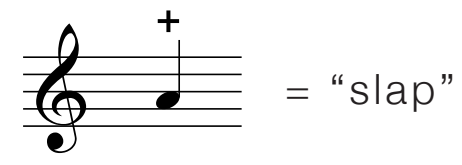

(4) Idem (1) avec slap.

(5) Percussion alternée entre le pouce et le petit doigt de la main droite sur les clés suivantes: $\mathbb{O} \bigcirc \notin 0$

Fa\#

(6) Pour la flûte en Do: sur chaque $\underline{\underline{0}}$ temps monter le son en tournant la flûte. Il faut une progression entre ces micro-intervalles jusqu'à atteindre le demi-ton au $\boldsymbol{f f f}$. La flûte en Sol pratique de même, mais en abaissant le son à chaque fois. 
RevistaMúsica, v 21 n. 2 - Dossiê O legado musical de Arnold Schoenberg e seus reflexos na América Latina: 1951-2021 Universidade de São Paulo, julho de 2021 ISSN 2238-7625 


\section{Avant-Retard}

Para Flauta em Do e Flauta em Sol

(Pour Flûte en Do et Flûte en Sol)

(A) $D=200$

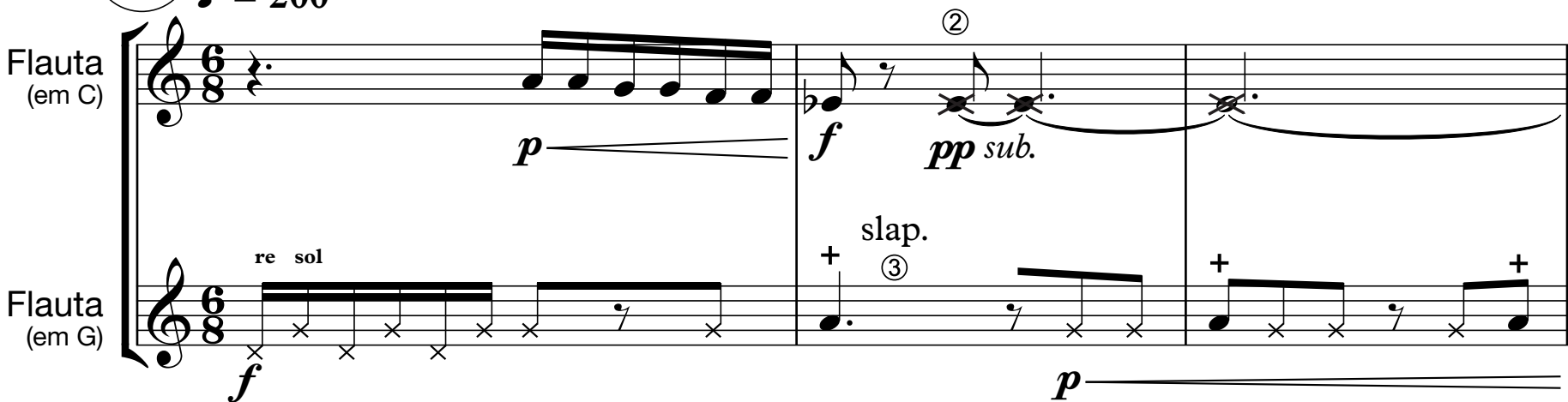

$\mathrm{C} \mathrm{FI}$.

4

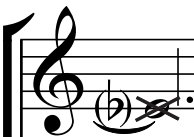

$\mathrm{G} \mathrm{FI}$
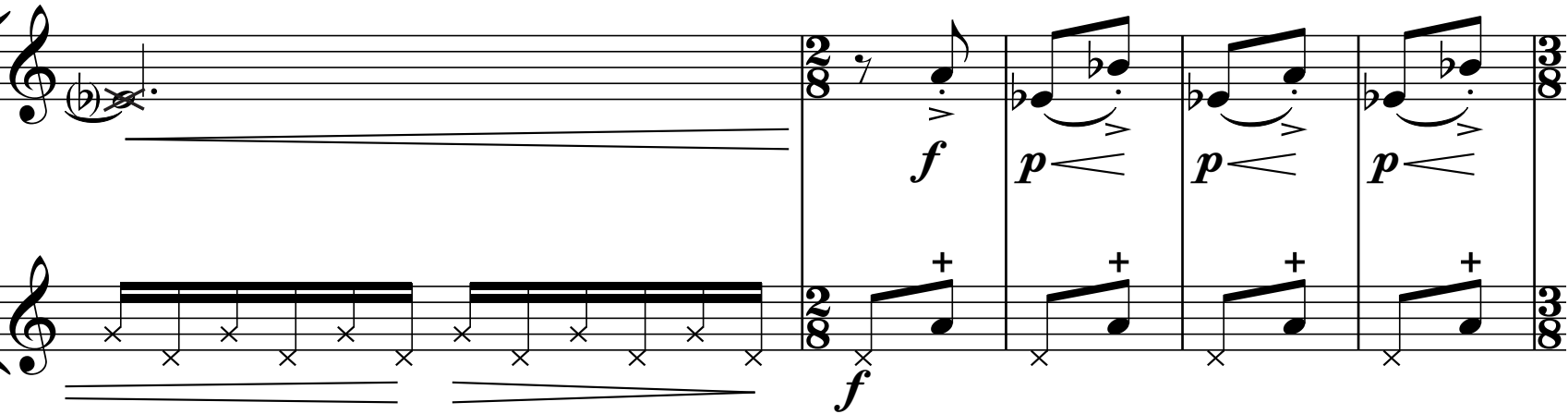

C Fl.

9

G FI.

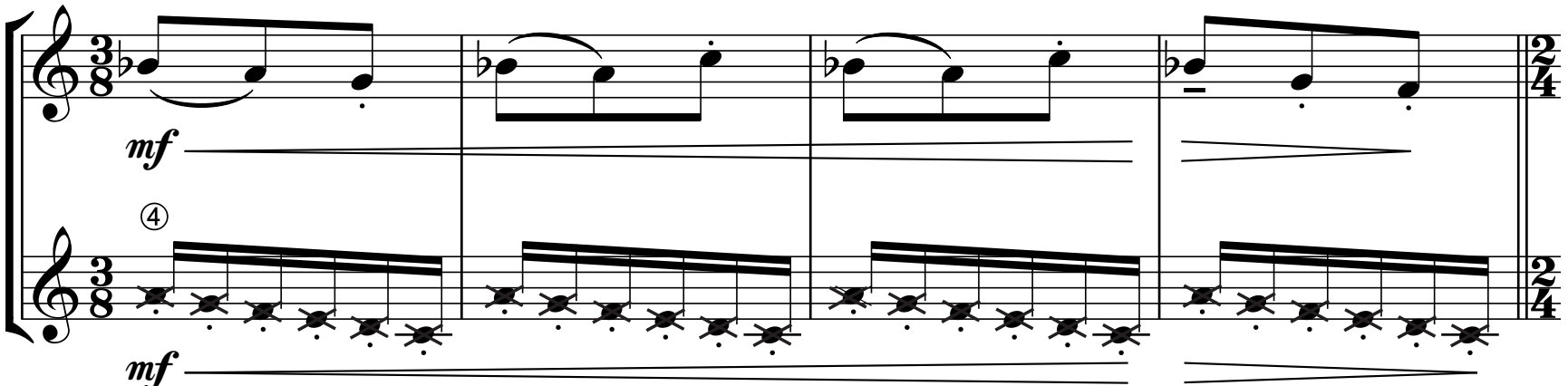

C Fl.

$13 \cdot=\AA \longrightarrow$ sempre

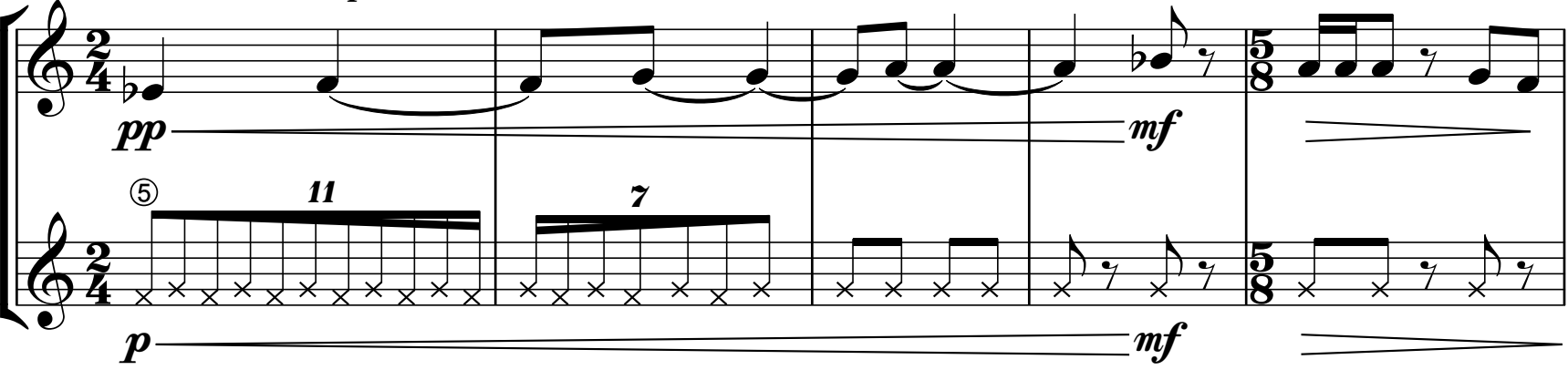

G Fl. 
C FI.

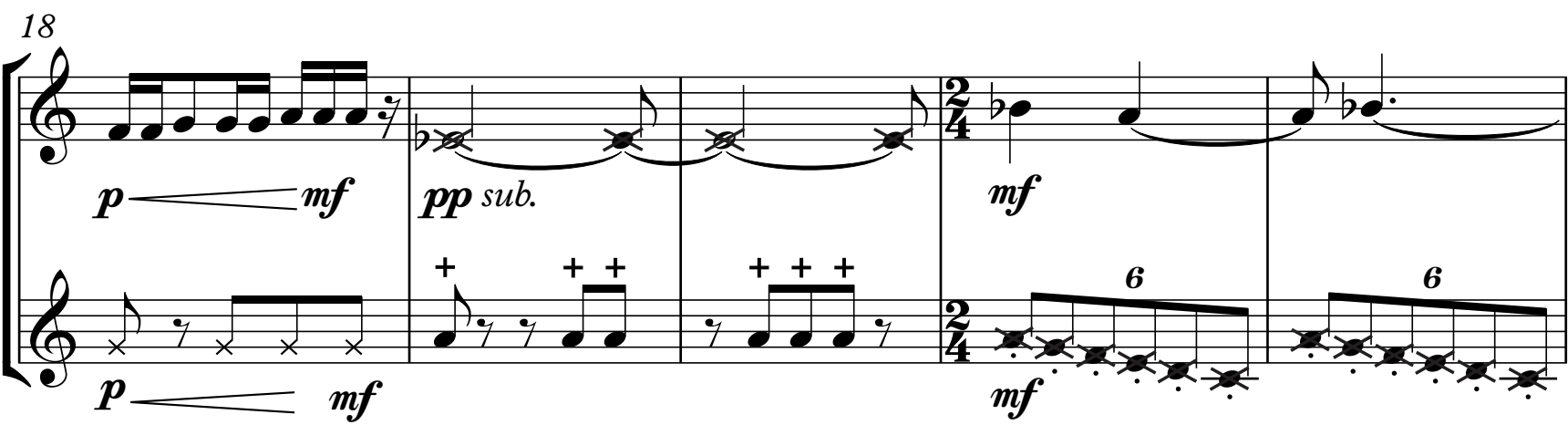

C FI.

G FI.

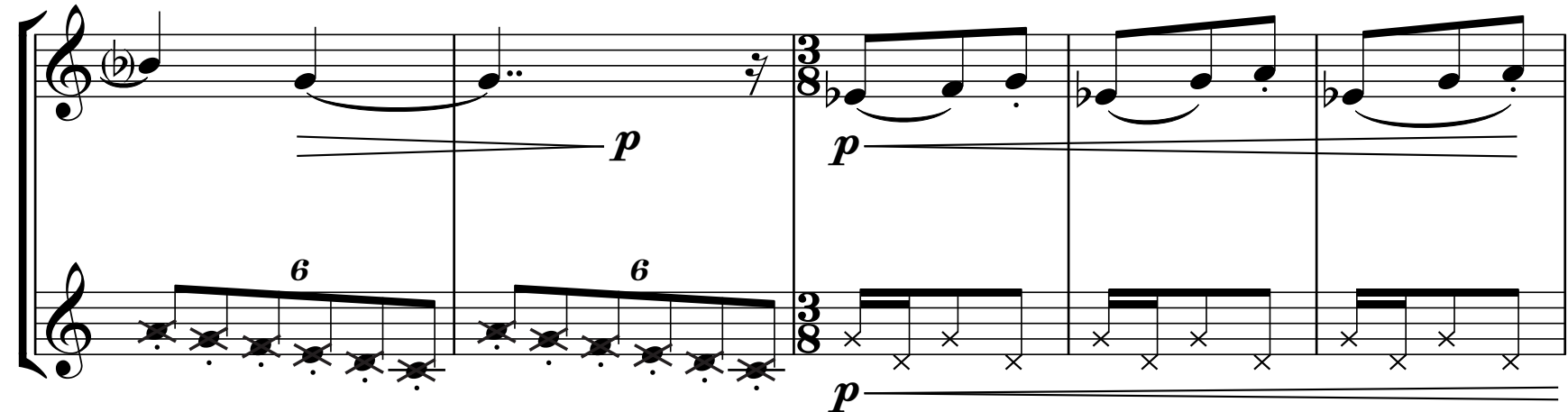

$\mathrm{C} \mathrm{FI}$.

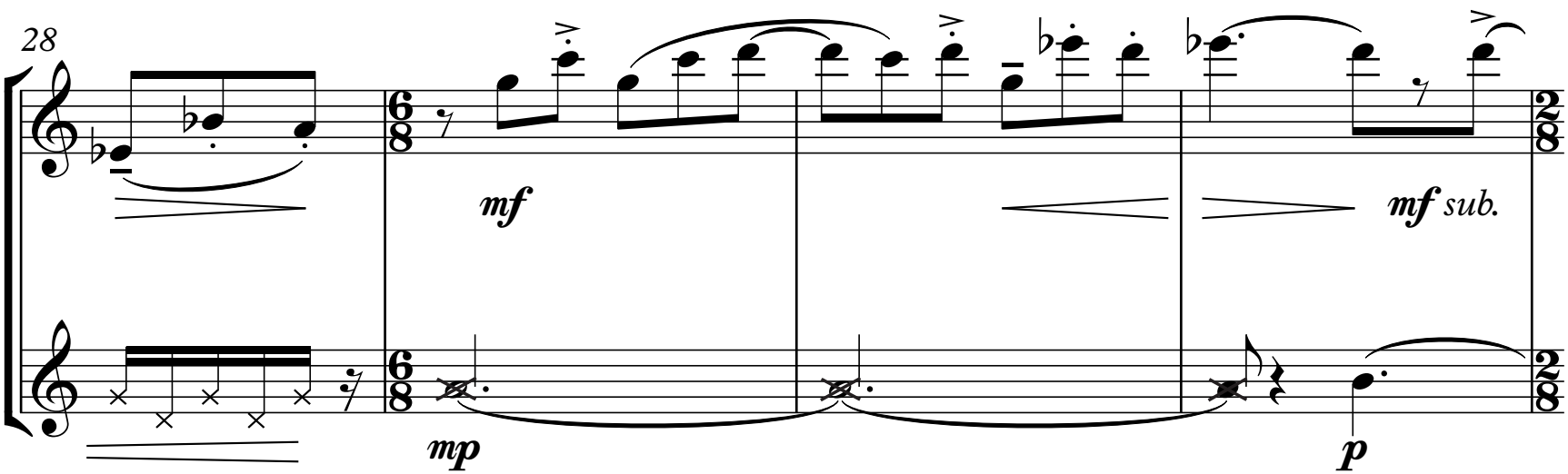

$\mathrm{C} \mathrm{FI}$.

accel.

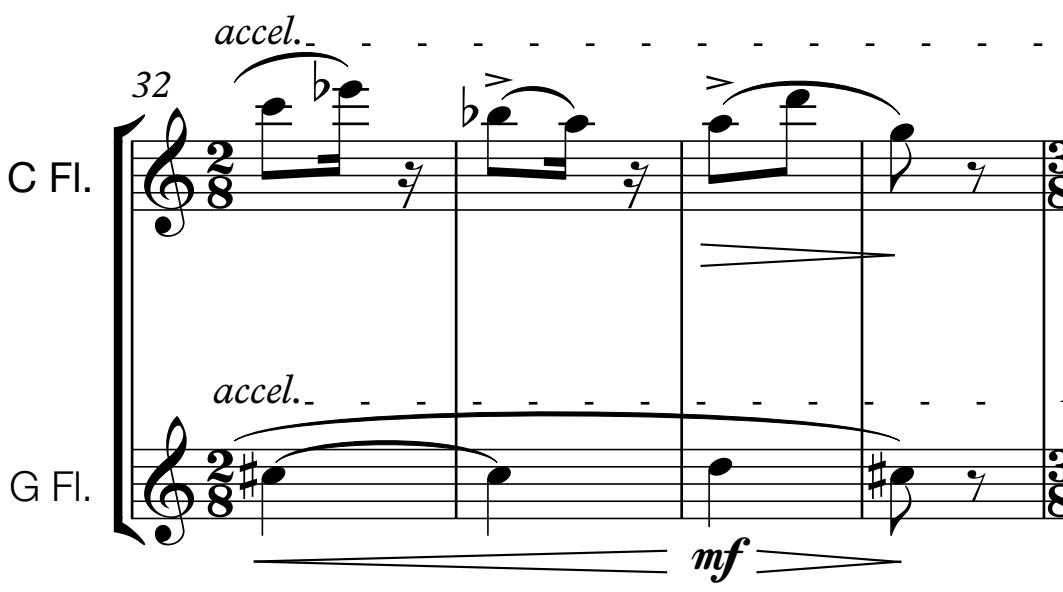

A tempo

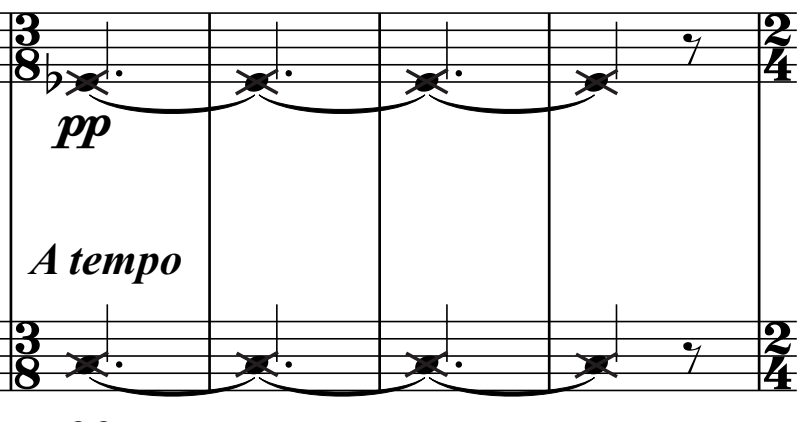


C FI.

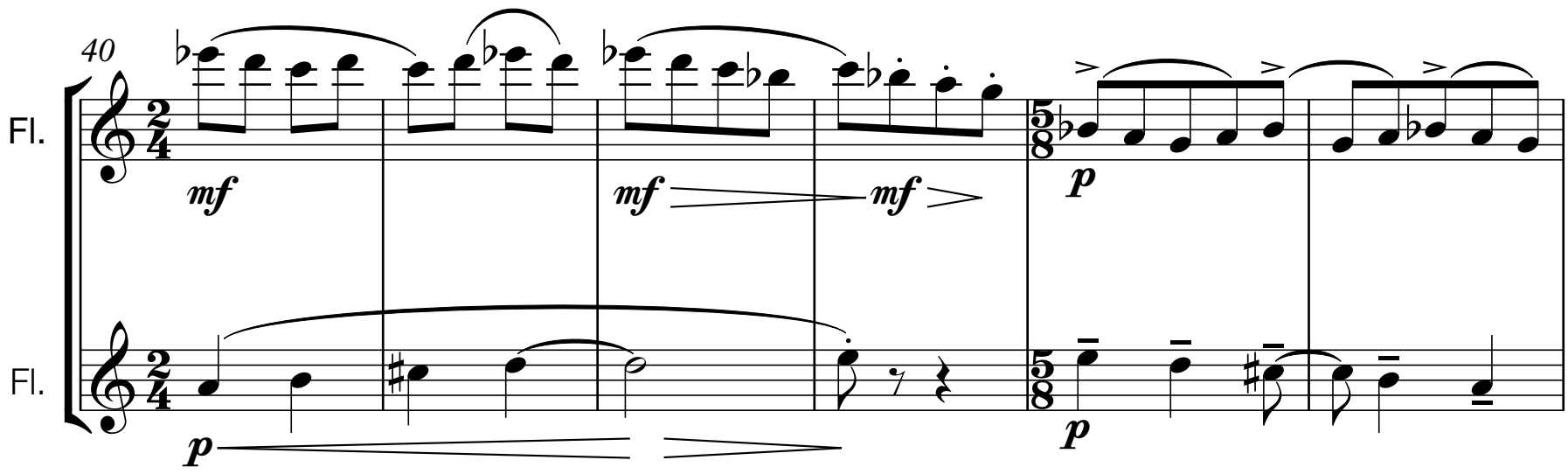

G Fl.

G FI.

C Fl.

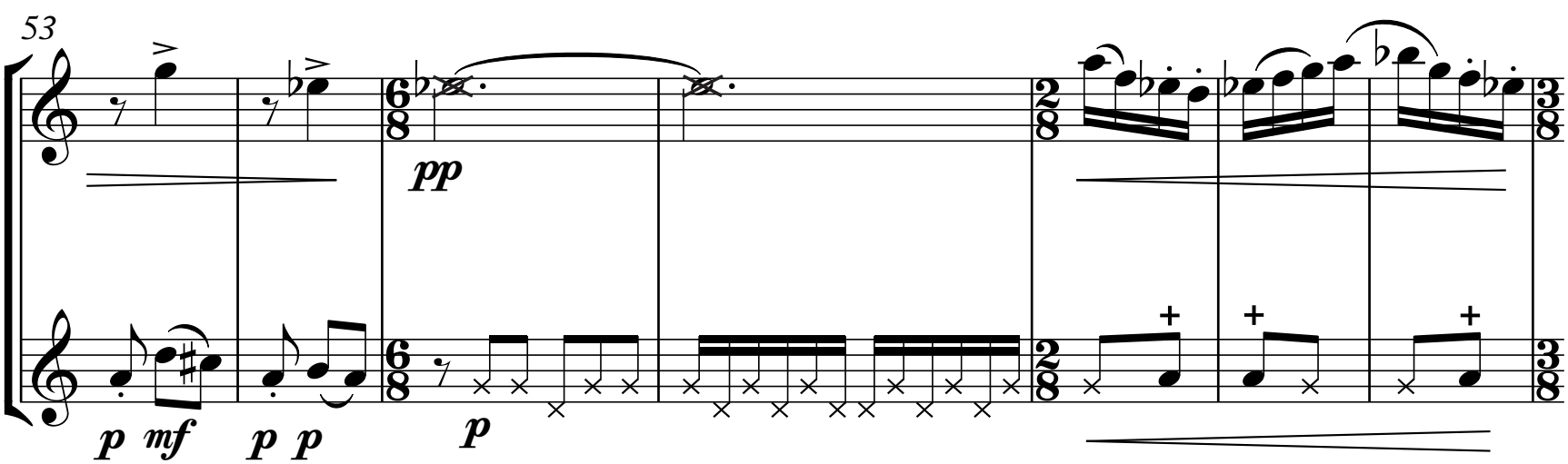

C FI.

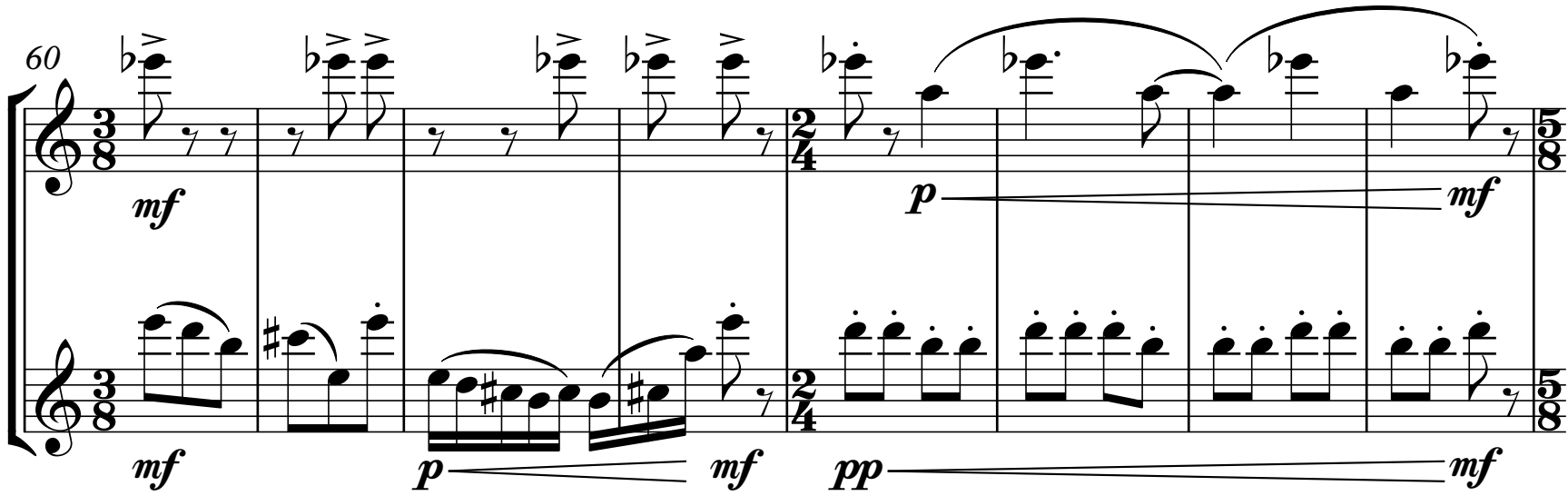


C FI.

68

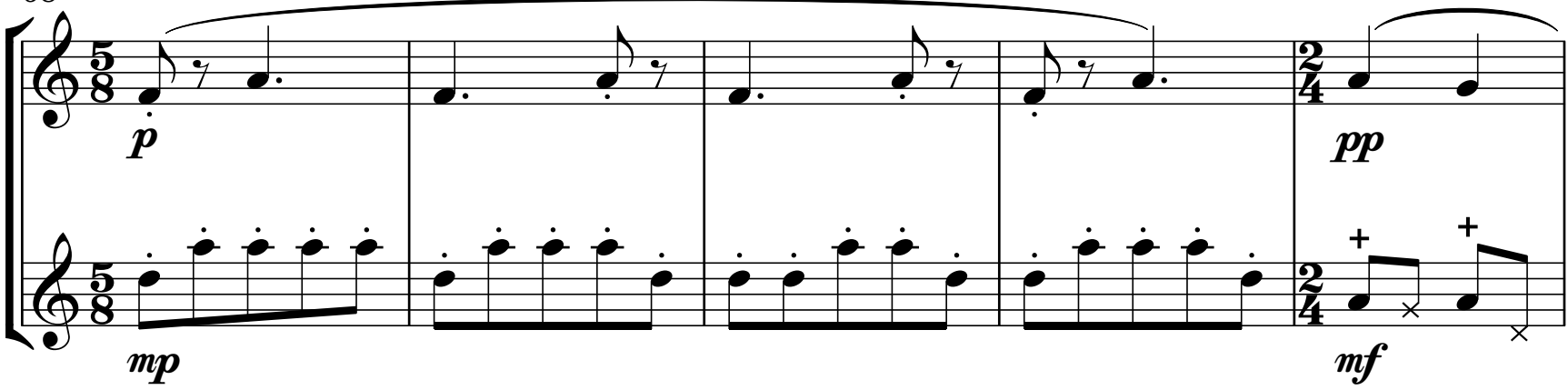

G Fl.

$$
m p
$$

C Fl.

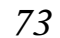

G Fl.

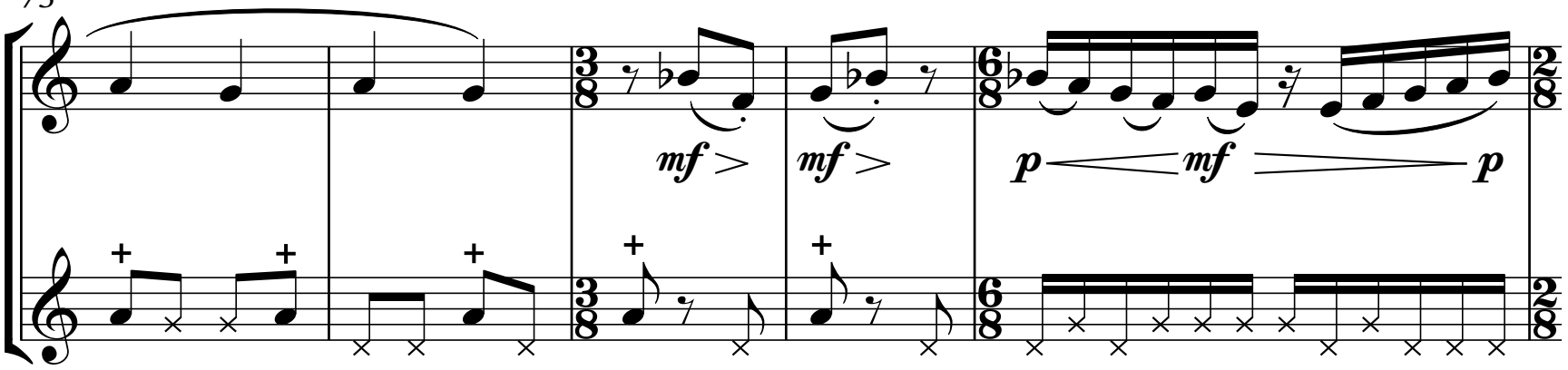

C FI.

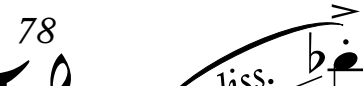

G Fl.
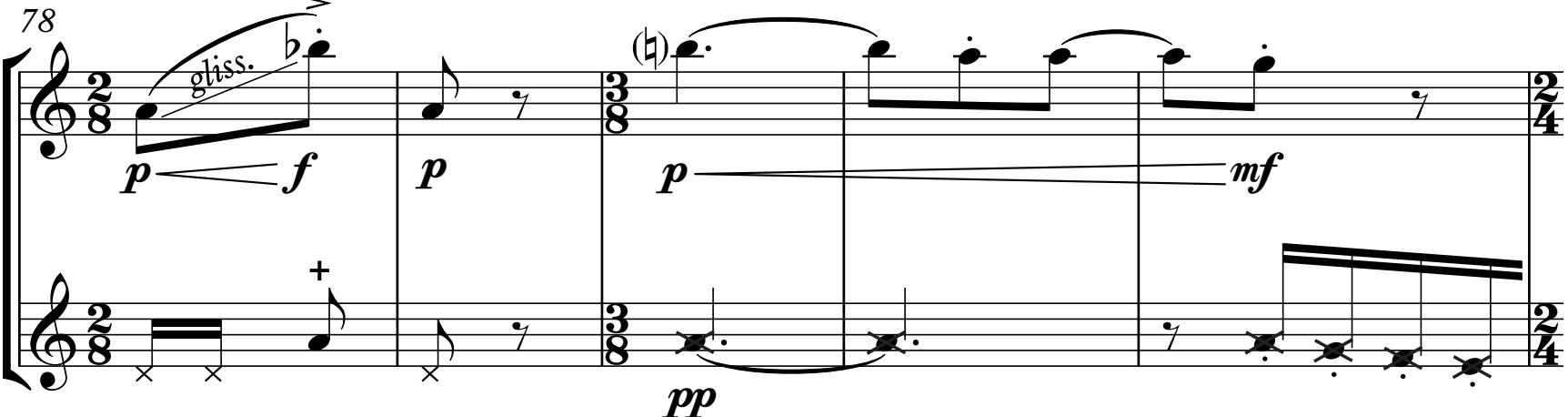

83

C Fl.

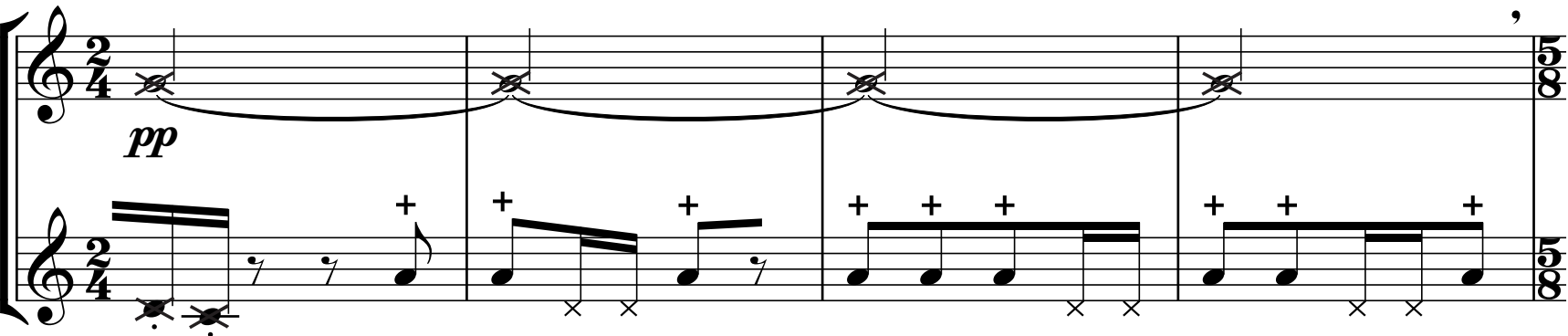

G Fl.

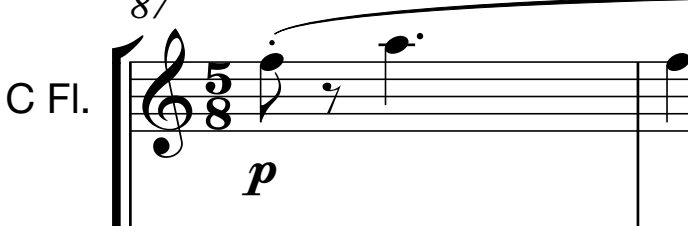

87

$i+i+i$

G Fl.

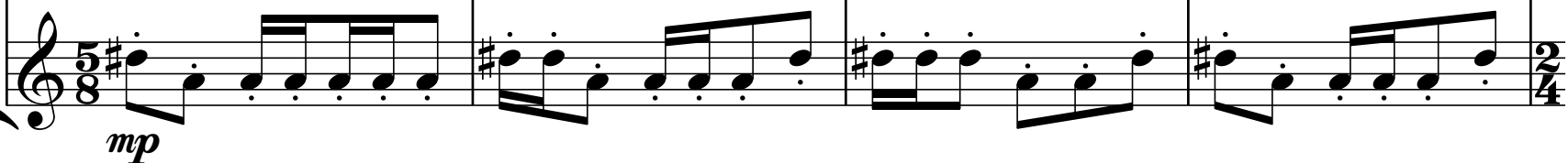



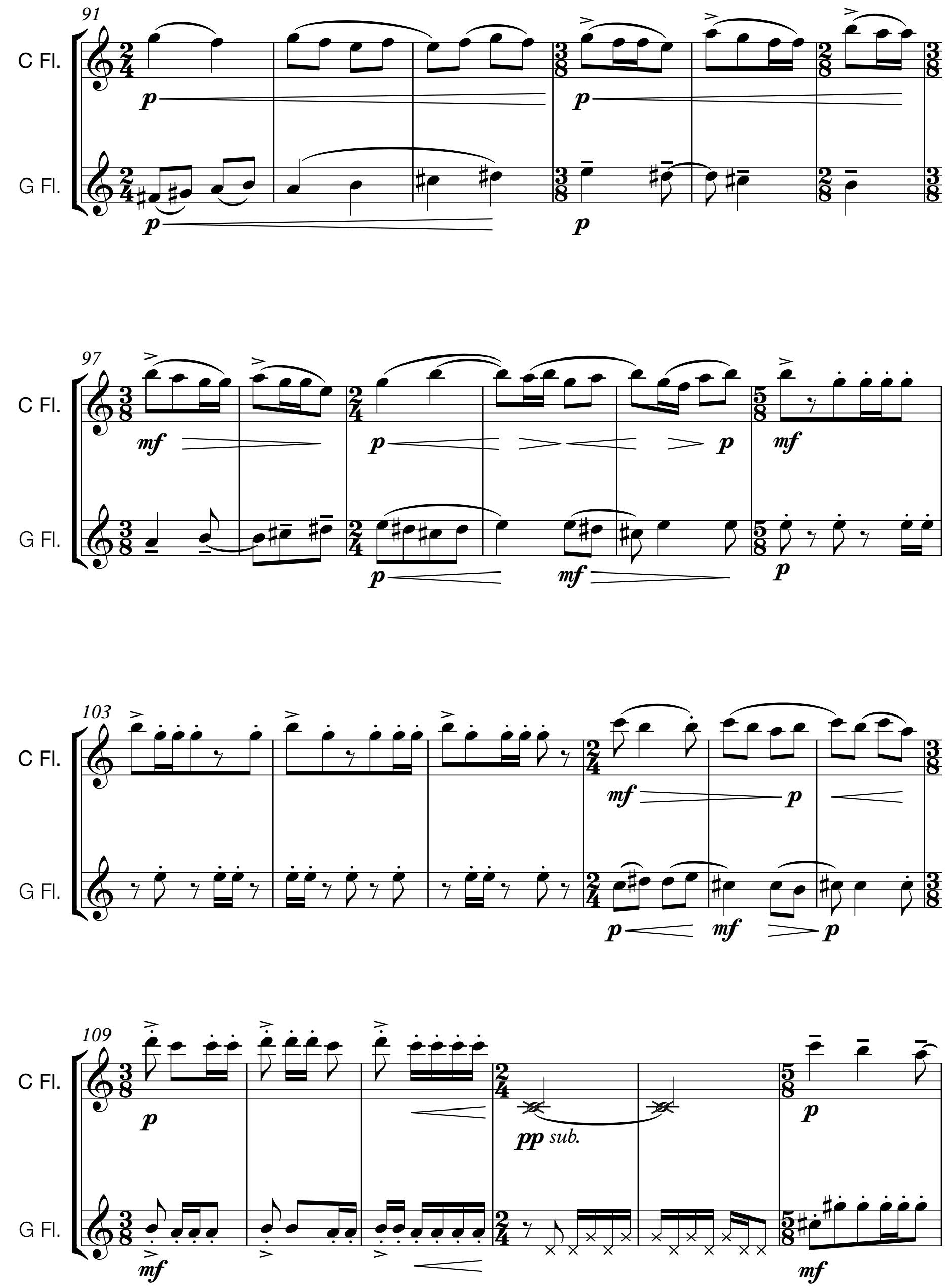
6

C Fl.

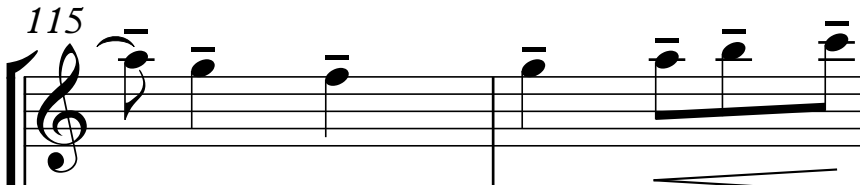

G Fl.
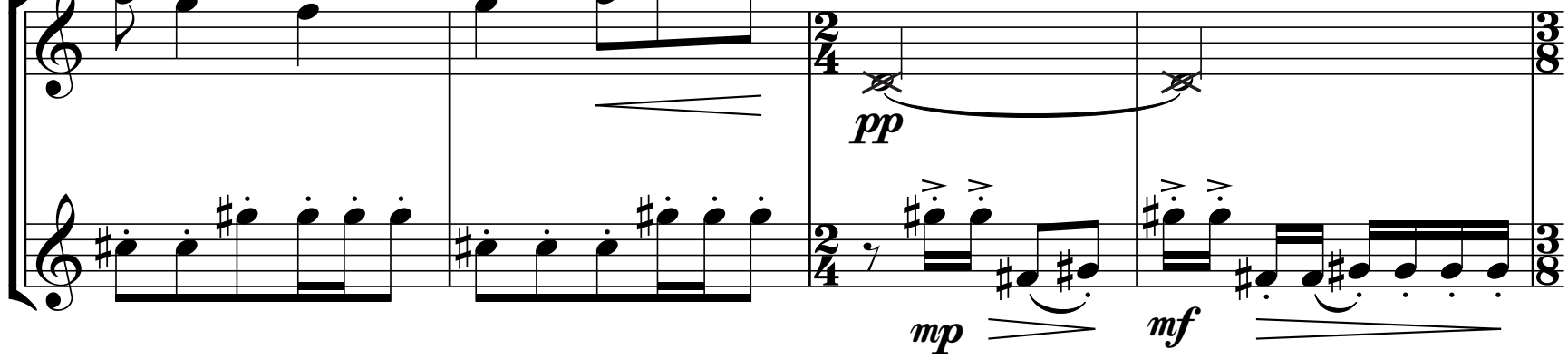

$\mathrm{C} \mathrm{Fl}$.

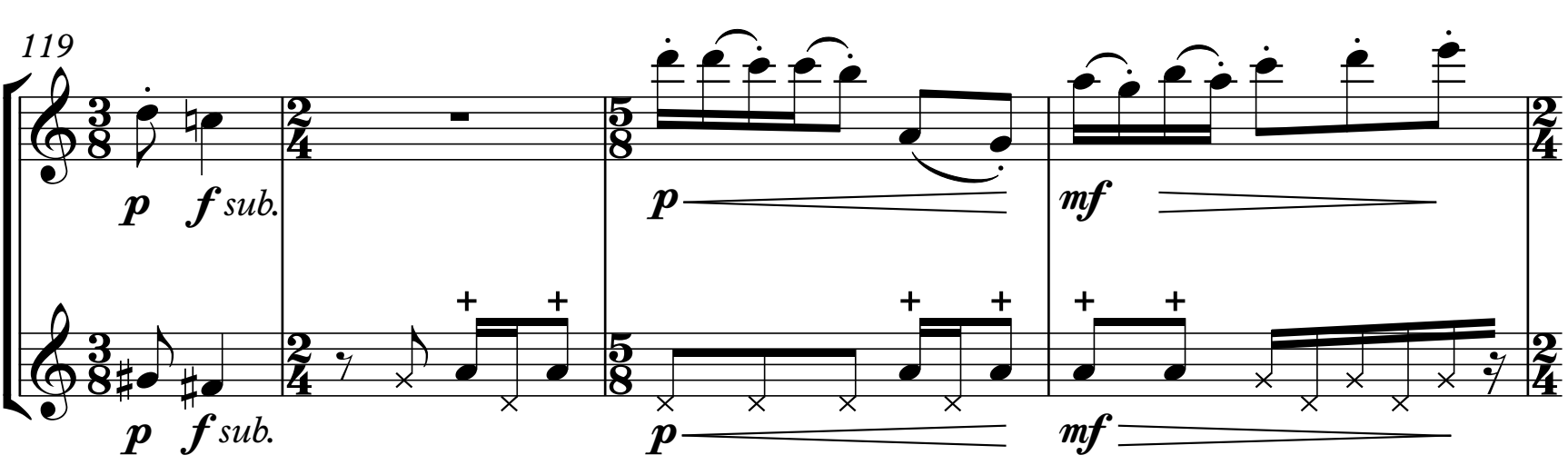

G FI.

$$
\text { p } \boldsymbol{f} s u b \text {. }
$$

C FI.

$$
\text { (B) } \underset{*}{\operatorname{meno}} \stackrel{\rho}{=}(d=176)
$$

G Fl.

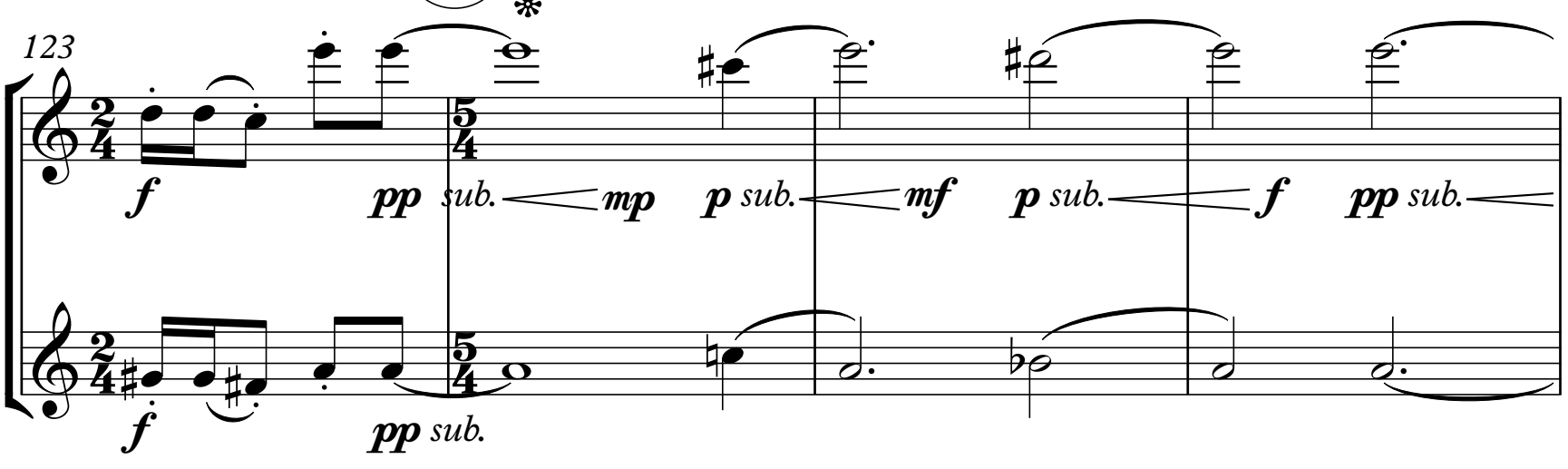

C FI.

127 定

- te $\frac{H e}{2}$

He

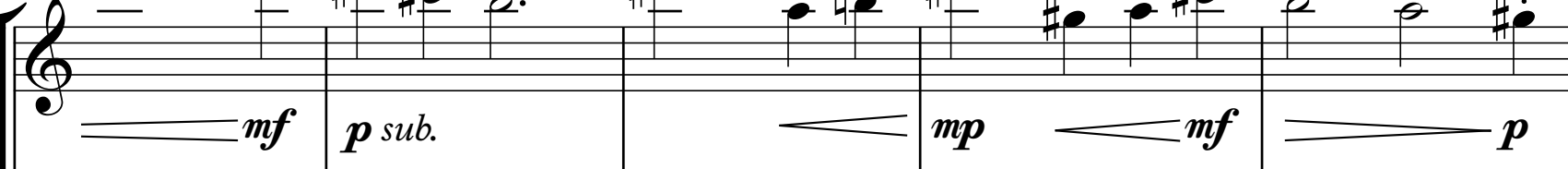

G Fl.

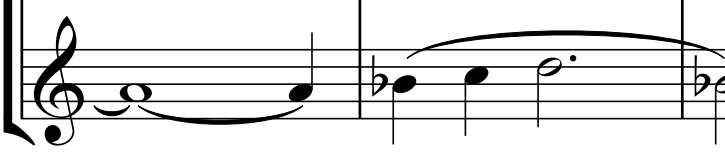

* De (B) à , a Flauta em Do deve tocar "DETIMBRÉ"
* De B à , la Flûte en Do doit jouer "DETIMBRÉ" 

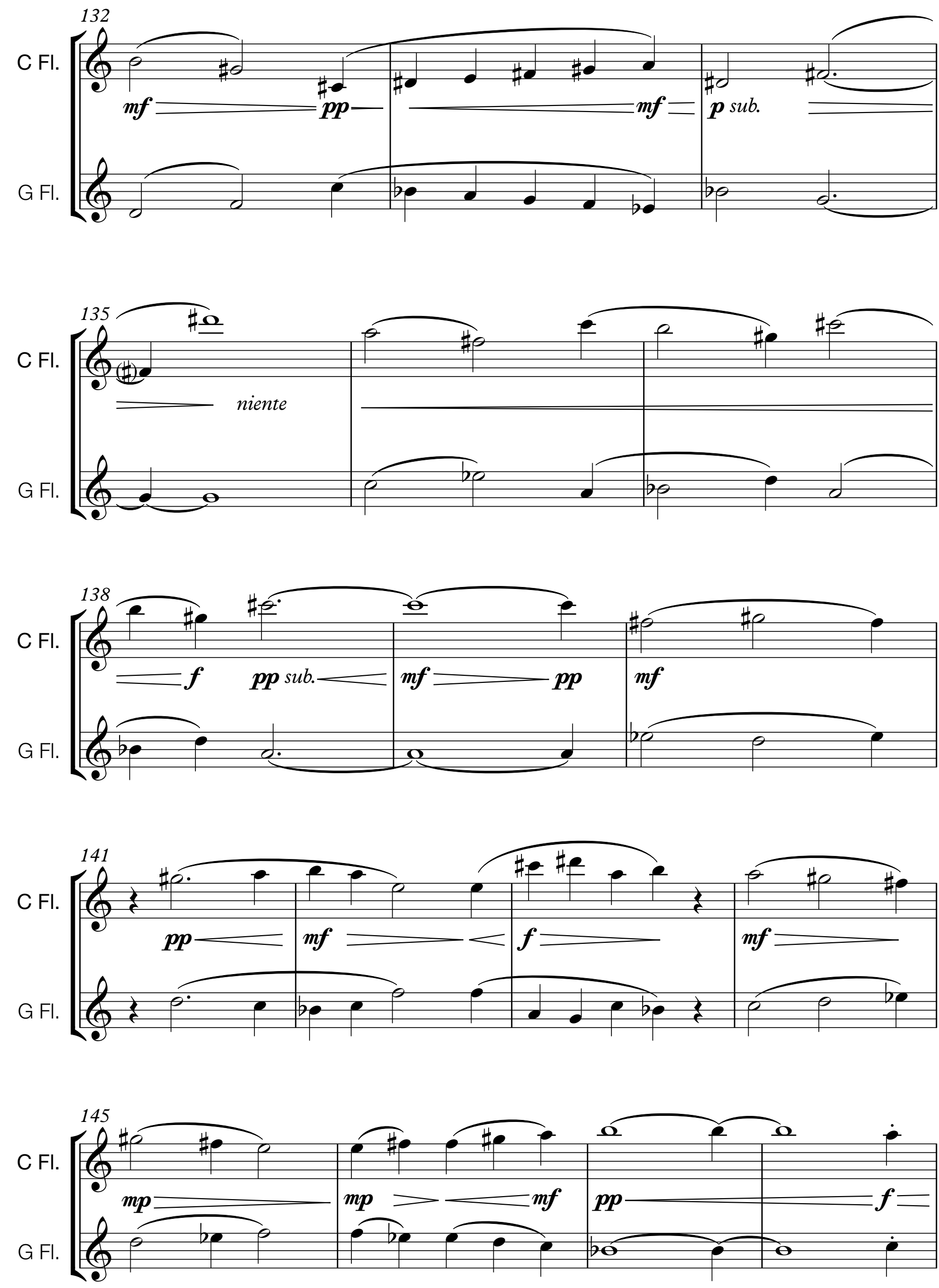
8

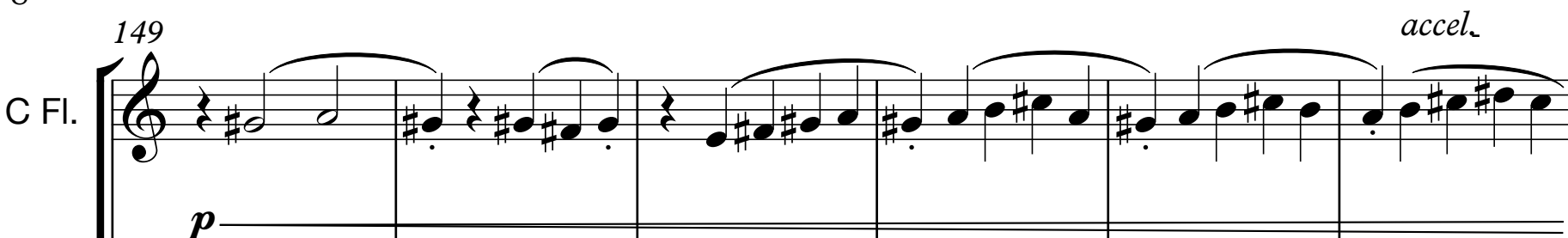

G Fl.

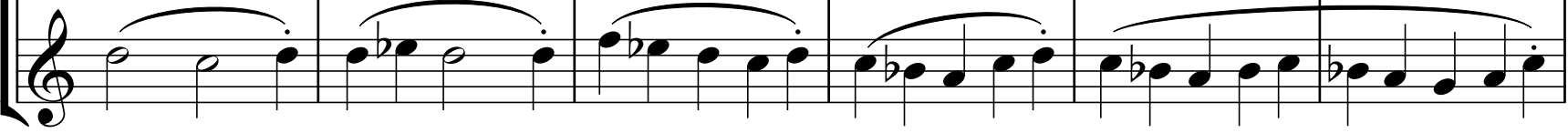

G FI.

155

un------.-poco

C FI.

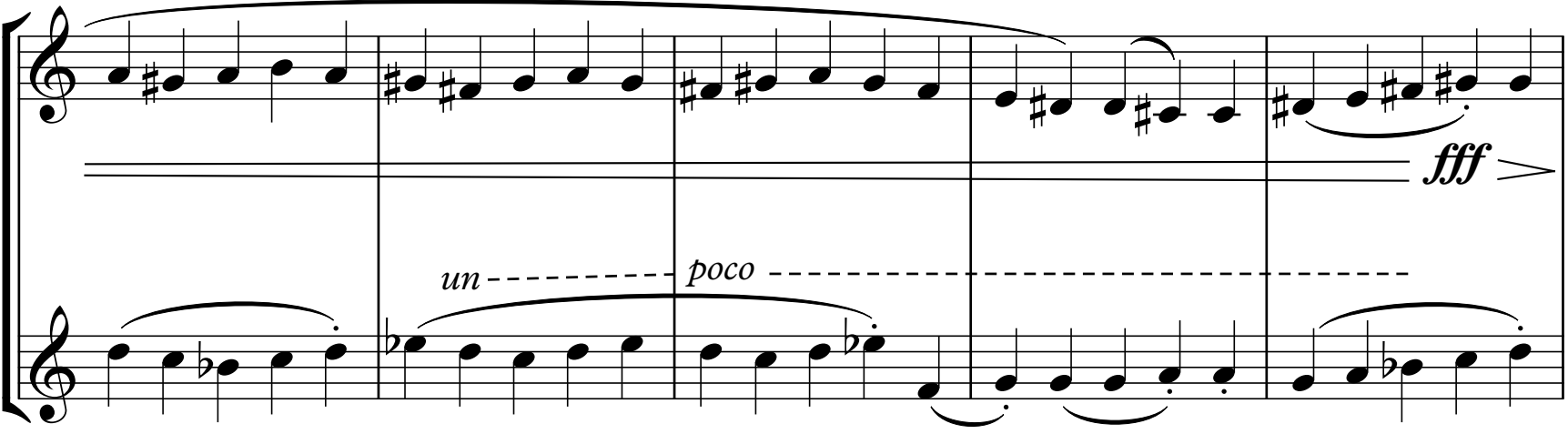

A tempo $(\downarrow=176)$

C Fl.

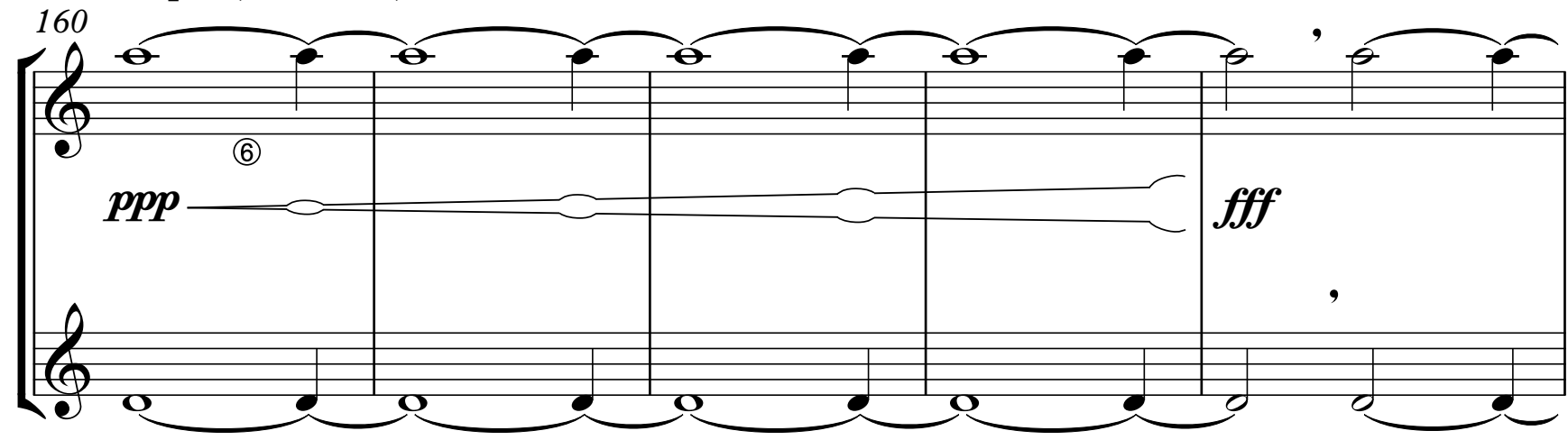

$\mathrm{C} \mathrm{FI}$.

165

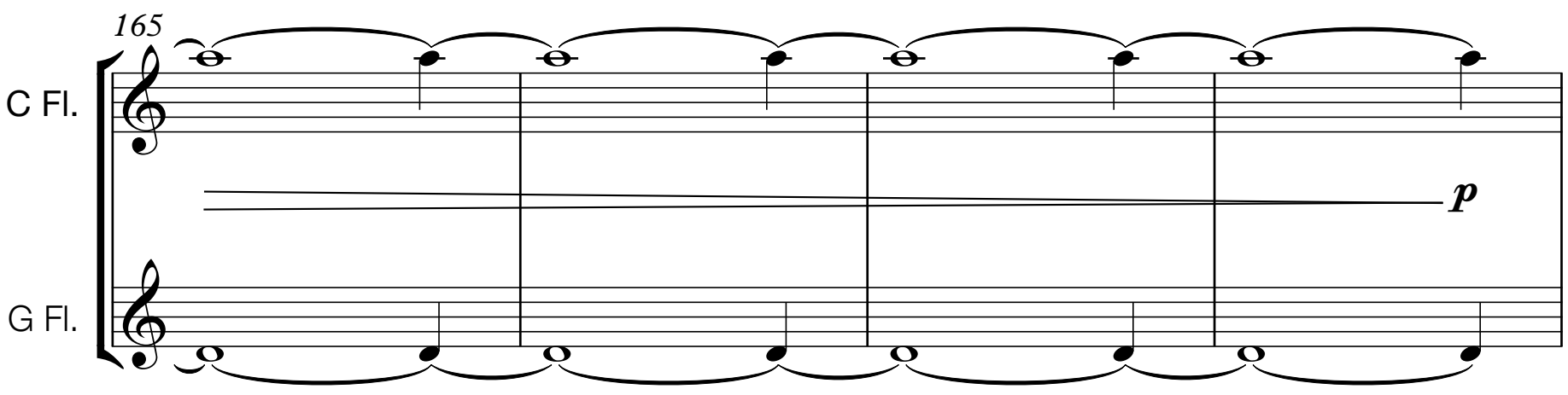




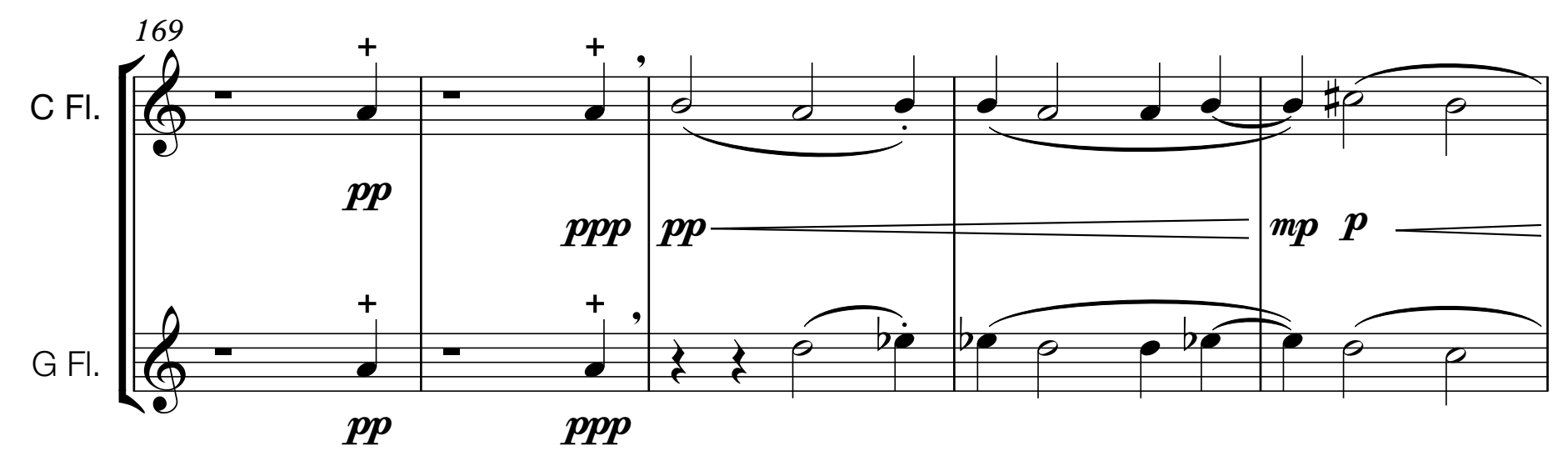

174

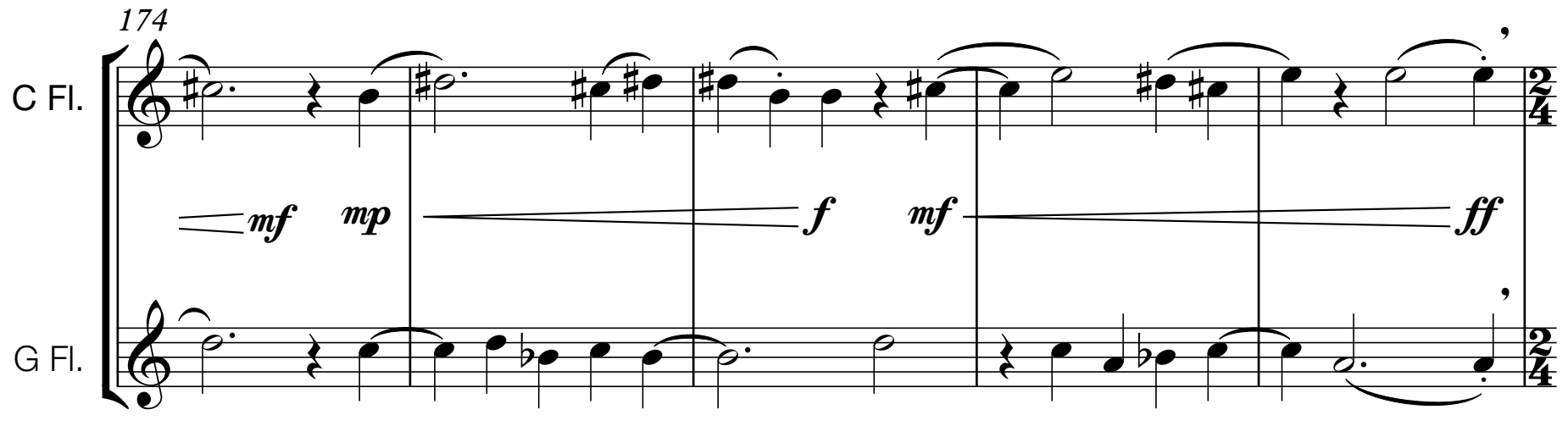

(C) $\underset{179}{\operatorname{Tempo} I}={ }^{\dagger}\left({ }^{\dagger}=200\right)$
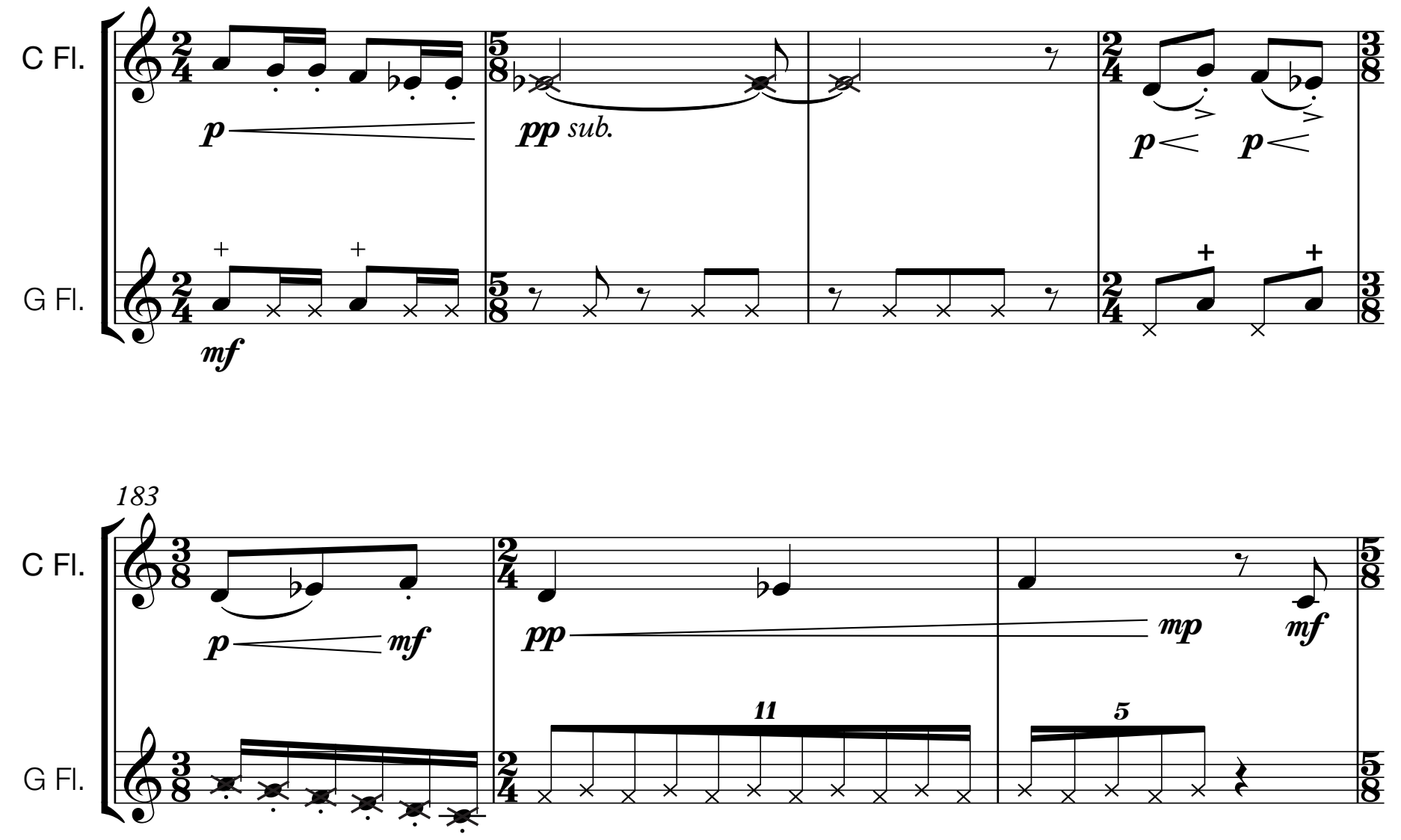
C FI.

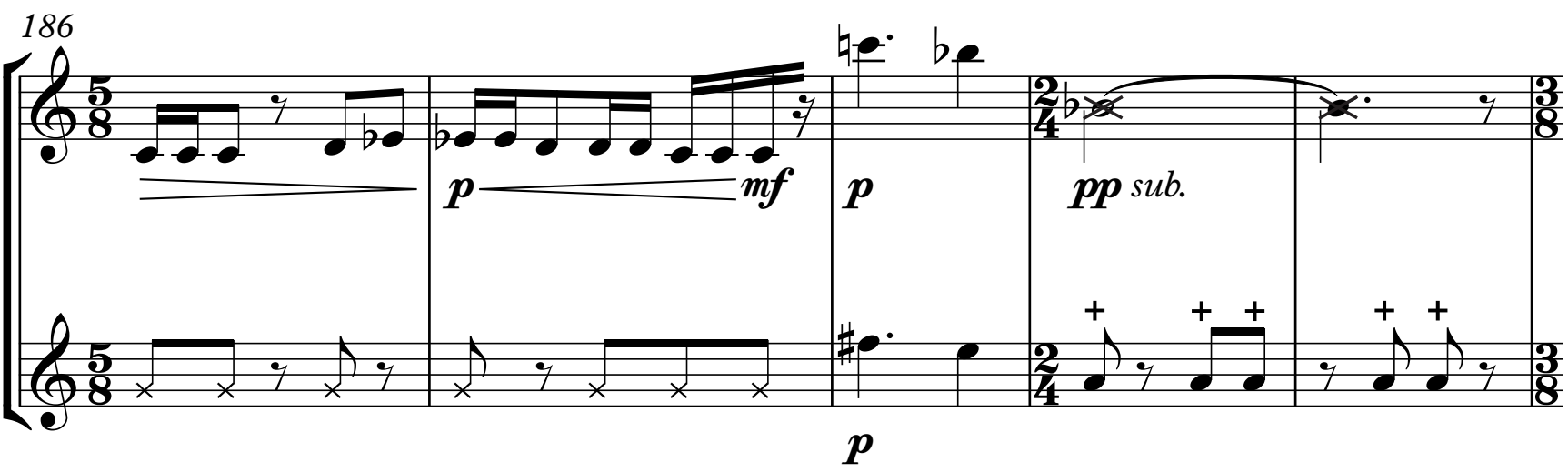

C Fl.

191

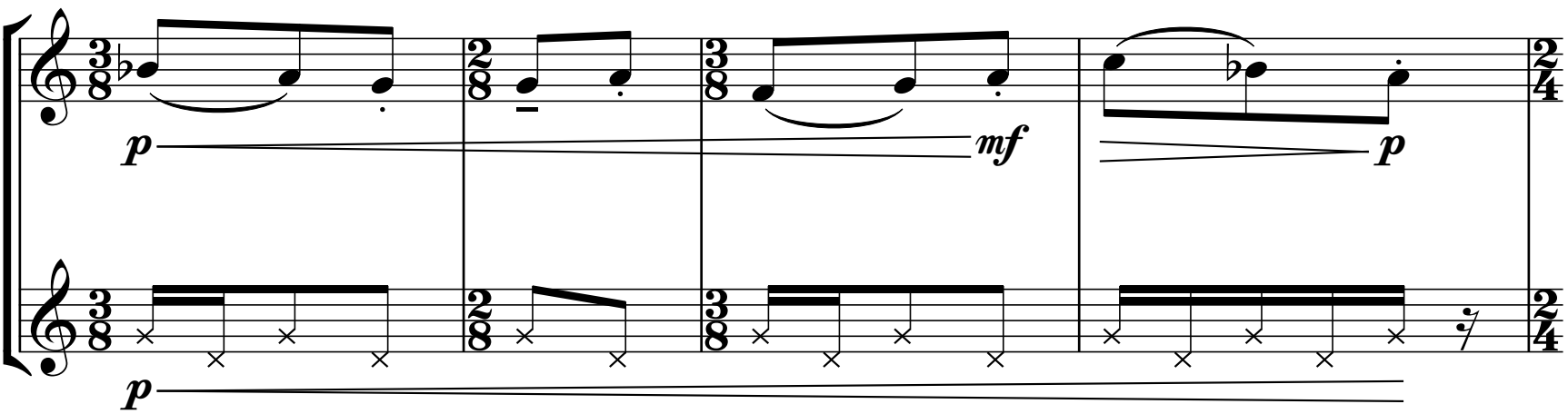

C Fl.

195

G Fl.

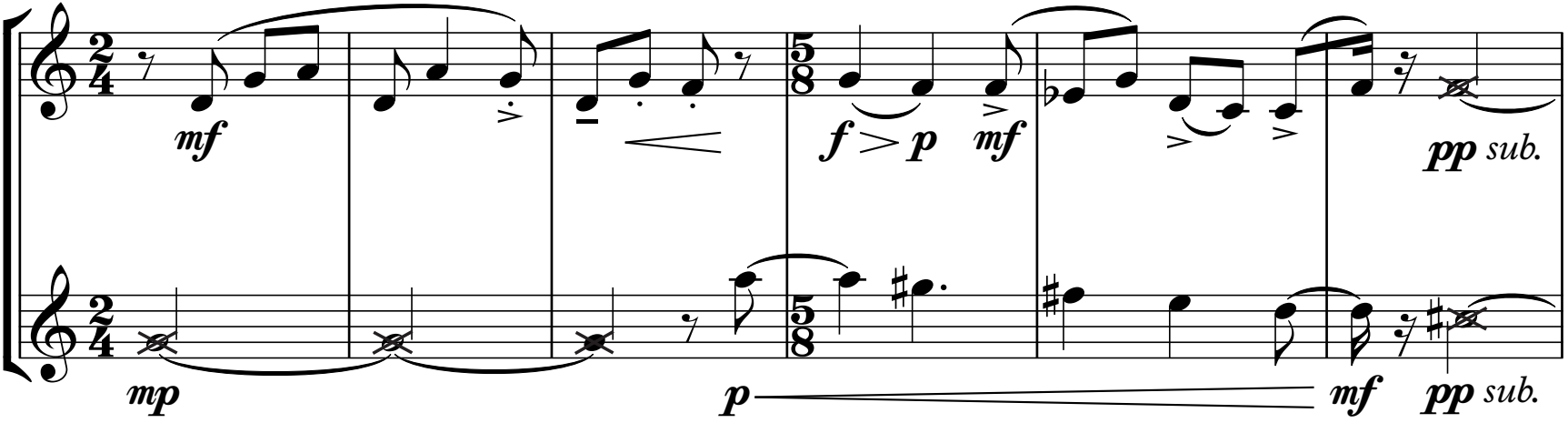

C Fl.

201

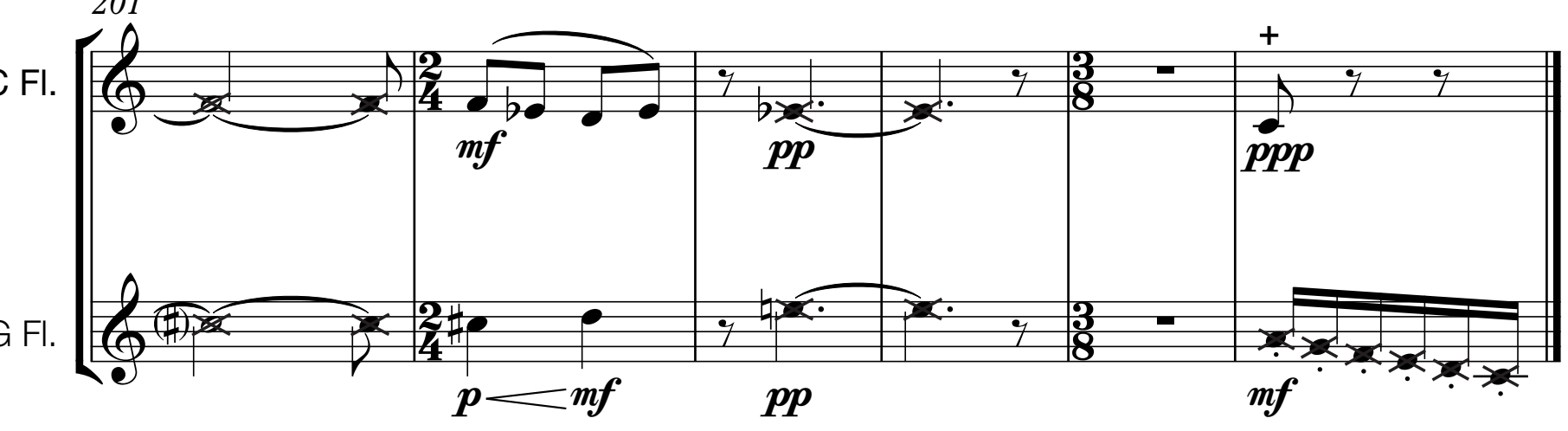

Duração:

Durée: 4'30" 
RM-389 PROJETO PARA DUO DE FLAUTAS (em $C$ e G)

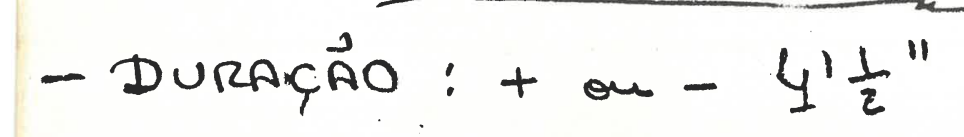

- Forma:: $\begin{array}{rll}A & B & A \\ I / I & \mathbb{I} & I\end{array}$

- Escalas: lídio 12345678

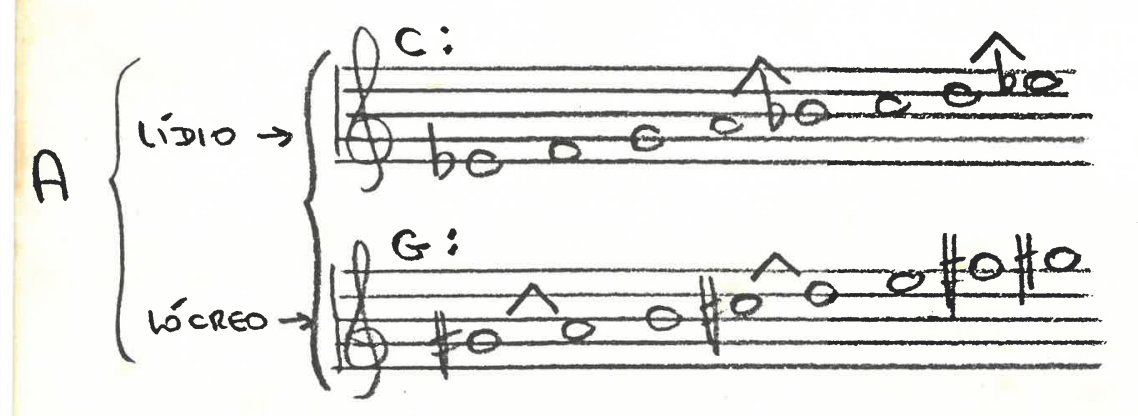

- Lócreo $\rightarrow$ bimodal

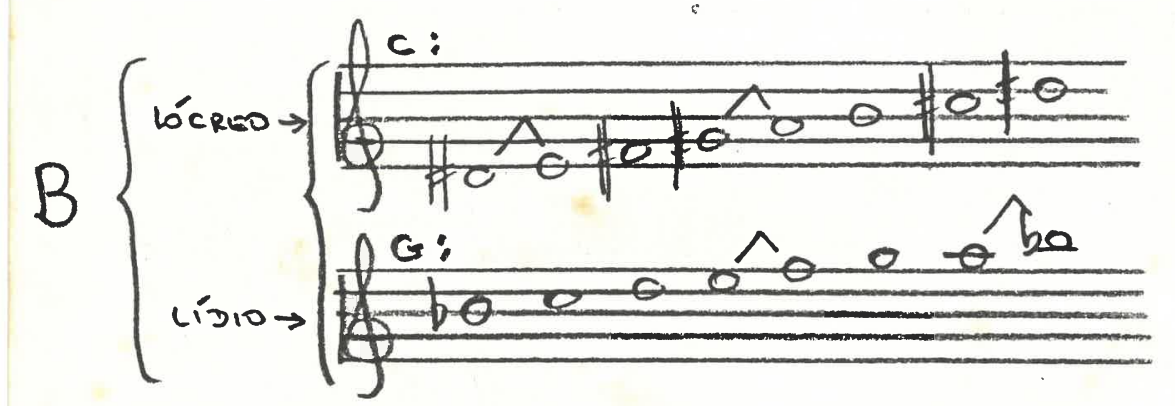

TESSITURA:

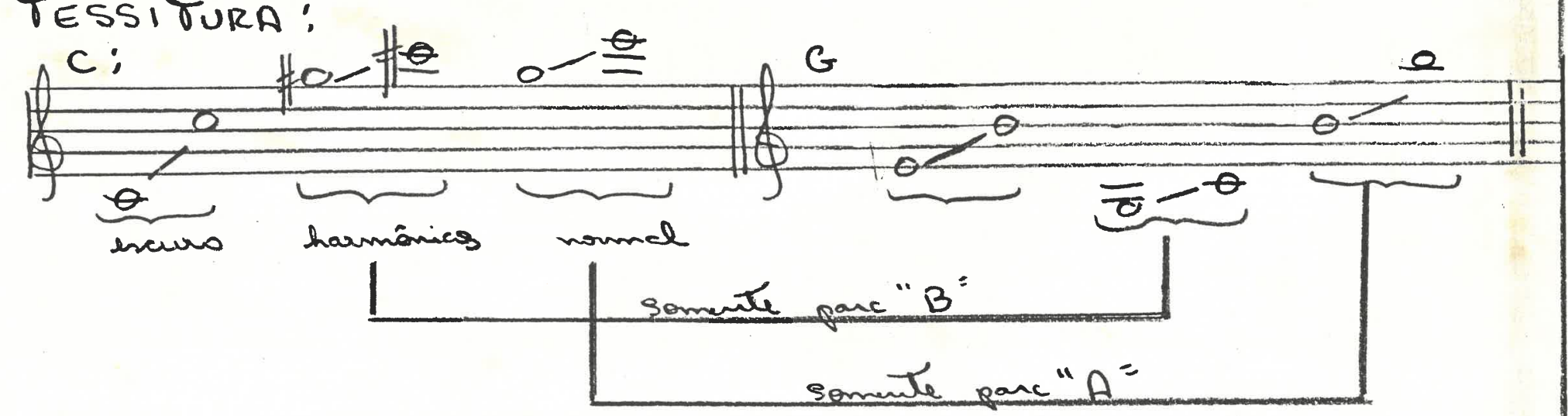
- Ríomo: PARVE $A \rightarrow$ rígido, com mudancos trepuntes de

PARVE B $\rightarrow$ "elástico", em compans úmico $\left(\frac{5}{8}\right)$

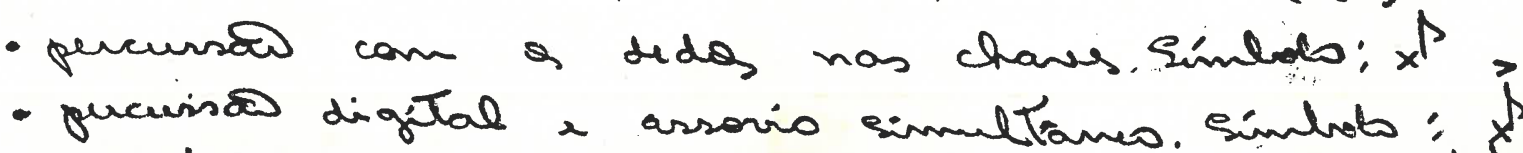

- canto em uninnono com a notc tocadc. " :

- ercalc descendute en pucursas digtal. "1

- Votr com recilaciosos té $\frac{1}{2}$ ton enpuiar e infuia.

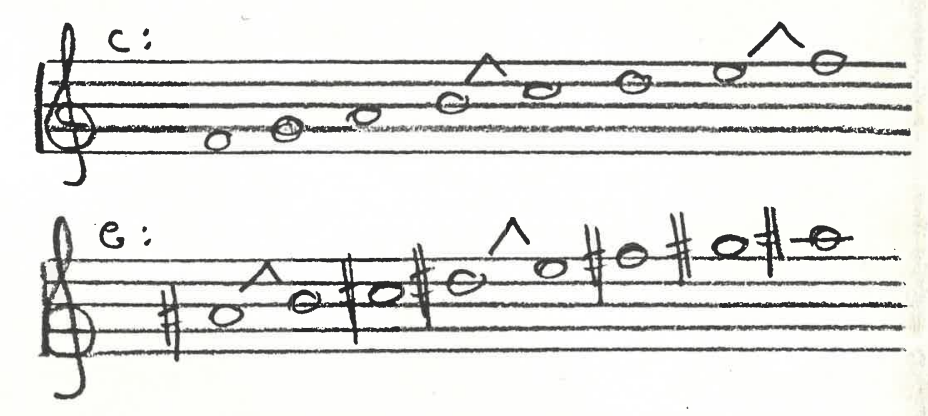
$v^{2} V^{5678}$ Simblolo: tran

Universidade de São Paulo, julho de 2021 ISSN 2238-7625

$\left\{\begin{array}{l}4 \\ 3 \\ 2\end{array}\right.$

$B[0$

$A \begin{cases}0 & 0 \\ 0 & 0 \\ 0 & 1\end{cases}$ $\frac{2}{4} \quad \int_{8}^{\operatorname{cimax}} \frac{2}{4} \quad \frac{3}{8}=27$.

$\frac{6}{8} \quad \frac{2}{8} \quad \frac{3}{8}$

$\begin{array}{lllllll}4 & 4 & 4 & 4 & 4 & 4 & 4\end{array}$

$\begin{array}{lllllll}3 & 4 & 4 & 4 & 4 & 4 & 3\end{array}=99$

$344 \quad 4 \quad 4 \quad 3 \quad 2=84$

$2 \quad 3 \quad 4 \quad 4 \quad 3 \quad 2=73$

1

2

43

$2=58$

$321=37$

21

$0=28$

600

$0] \rightarrow \times 60=300$ $=+$ on $-1^{\prime \prime} \frac{1}{2}$

P.S. $P=200$ 


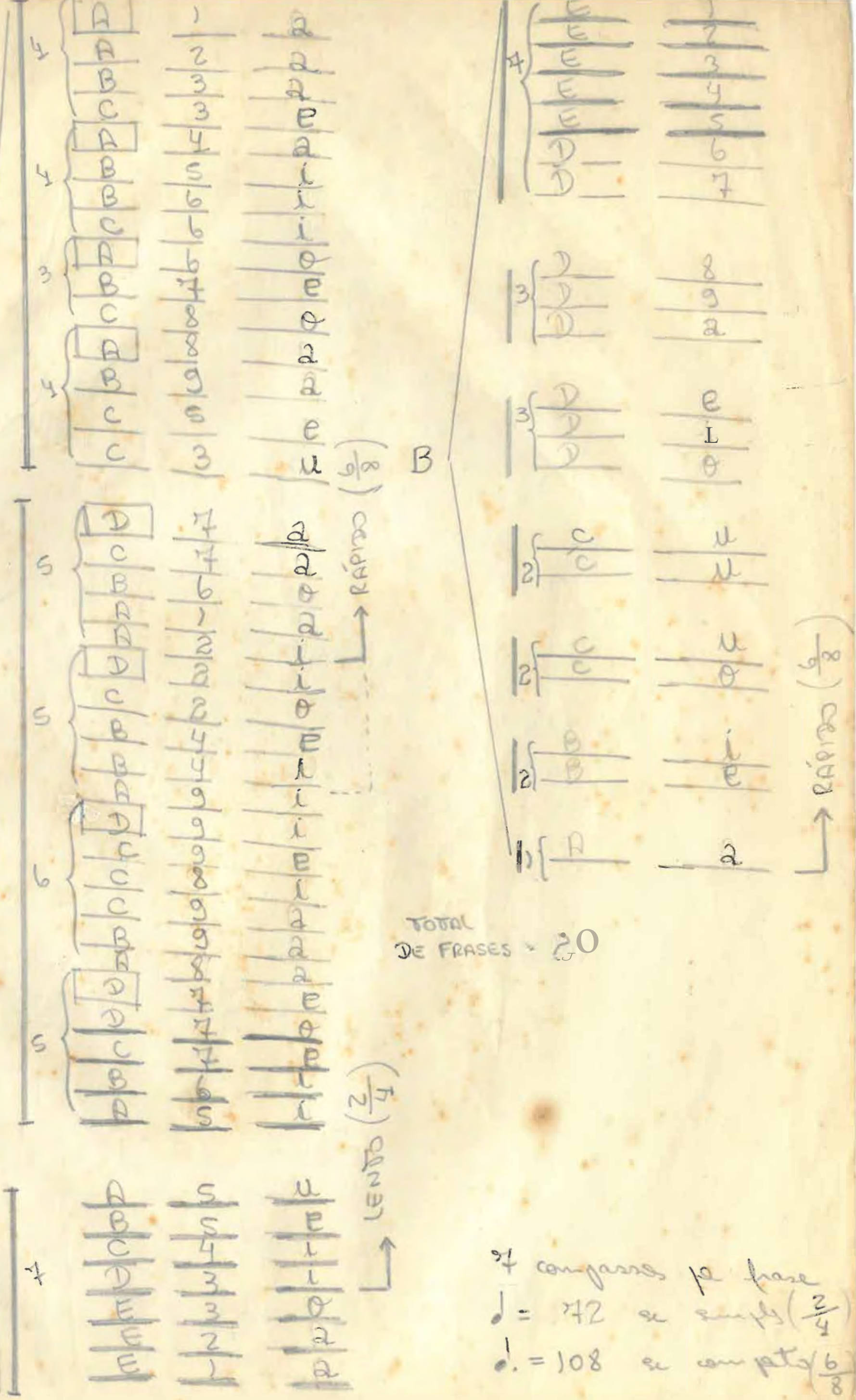

Total

RevistaMúsica, v. 21 n. 2 - Dossiê 0 legado musical de Arnold Schoenberg e seus reflexos na América Latina: 1951-2021

Universidade de São Paulo, julho de 2021 ISSN 2238-7625 